\title{
Symbiotic interactions between chickpea (Cicer arietinum L.) genotypes and Mesorhizobium strains
}

\author{
A. H. Gunnabo ${ }^{1}$ (D) J. van Heerwaarden ${ }^{1} \cdot$ R. Geurts ${ }^{2} \cdot$ E. Wolde-meskel ${ }^{3} \cdot$ T. Degefu ${ }^{4} \cdot$ K. E. Giller $^{1}$
}

Received: 25 April 2020 / Accepted: 17 September 2020 / Published online: 30 September 2020

(C) The Author(s) 2020

\begin{abstract}
Legume genotype $\left(G_{L}\right)$ x rhizobium genotype $\left(G_{R}\right)$ interaction in chickpea was studied using a genetically diverse set of accessions and rhizobium strains in modified Leonard Jars. A subset of effective $G_{L} \times G_{R}$ combinations was subsequently evaluated in a pot experiment to identify combinations of chickpea genotypes and rhizobium strains with stable and superior symbiotic performance. A linear mixed model was employed to analyse the occurrence of $G_{L} \times G_{R}$ interaction and an additive main effects and multiplicative interaction (AMMI) model was used to study patterns in the performance of genotype-strain combinations. We found statistically significant interaction in jars in terms of symbiotic effectiveness that was entirely due to the inclusion of one of the genotypes, ICC6263. No interaction was found in a subsequent pot experiment. The presence of two genetic groups (Kabuli and Desi genepools) did not affect interaction with Mesorhizobium strains. With the exception of a negative interaction with genotype ICC6263 in the jar experiment, the type strain Mesorhizobium ciceri LMG 14989 outperformed or equalled other strains on all chickpea genotypes in both jar and pot experiments. Similar to earlier reports in common bean, our results suggest that efforts to find more effective strains may be more rewarding than aiming for identification of superior combinations of strains and genotypes.
\end{abstract}

Keywords AMMI · Genotype-strain combinations $\cdot$ Rhizobium genotypes $\cdot$ Symbiotic effectiveness

\section{Introduction}

Chickpea (Cicer arietinum L.) is an ancient legume crop of great economic importance; ranked third among the grain legumes in the world's agriculture after soybean and common bean (Plekhanova et al. 2017; Vishnyakova et al. 2017). It originated from Southeast Turkey and Syria, having its primary centre of diversity there with secondary centres of diversity

Electronic supplementary material The online version of this article (https://doi.org/10.1007/s13199-020-00724-6) contains supplementary material, which is available to authorized users.

A. H. Gunnabo

ashenafigunabo@gmail.com

1 Plant Production Systems Group, Wageningen University and Research, Wageningen, The Netherlands

2 Laboratory of Molecular Biology, Department of Plant Science, Wageningen University, Wageningen, The Netherlands

3 World Agroforestry (ICRAF), Addis Ababa, Ethiopia

4 International Crops Research Institute for the Semi-Arid Tropics, Addis Ababa, Ethiopia in India and Ethiopia (Zohary and Hopf 1973; Plekhanova et al. 2017; Vishnyakova et al. 2017). It is among the oldest legume crops in Ethiopia with archaeological evidence showing the presence of chickpea seeds in the caves of Lalibela dating back to 500 BC (Engels and Hawkes 1991).

In Africa, Ethiopia ranks first in chickpea cultivation in terms of area and production (Shiferaw et al. 2009). However, the national average production is only 1.7 ton $\mathrm{ha}^{-1}$ (Shiferaw et al. 2009; Tena et al. 2016a; Wolde-meskel et al. 2018), far below the potential yield of 5.0 ton ha ${ }^{-1}$ (Giller 2001; Keneni et al. 2011). Like elsewhere in sub-Saharan Africa, soil fertility and high fertiliser costs constrain production in Ethiopia, with smallholder farmers usually growing legumes without additional nutrients (Wolde-meskel et al. 2018). The application of rhizobial inoculants has therefore been proposed as a cost-effective way to enhance yields of chickpea (Wolde-meskel et al. 2018).

Although chickpea used to be considered a restrictive host (Laranjo et al. 2008; Alexandre et al. 2009; Armas-Capote et al. 2014), recent analysis has revealed that in addition to the well-known symbionts $M$. ciceri and $M$. mediterraneum it can establish symbiosis with several Mesorhizobium species like $M$. amorphae, M. loti, M. plurifarium, M. opportunistum, 
M. haukuii and M. tianshanense (Rivas et al. 2002; Maâtallah et al. 2002; Laranjo et al. 2004, 2008; Alexandre et al. 2009; Laranjo et al. 2012; Elias and Herridge 2015), M. wenxiniae WYCCWR $10195^{\mathrm{T}}$ and M. muleiense CCBAU $83963^{\mathrm{T}}$ (Zhang et al. 2018). These strains carry symbiotic genes (nifH and nodC) similar to the strains $M$. ciceri and $M$. mediterraneum that were previously considered to be the only symbionts of chickpea. In Mesorhizobium, the symbiotic genes are found on chromosomal islands that transferred horizontally between the strains (Laranjo et al. 2014; Lindström et al. 2015; Mousavi et al. 2016), potentially extending the host range for the mesorhizobial species as demonstrated recently in chickpea and bisserula (Laranjo et al. 2014; Elias and Herridge 2015). The horizontal gene transfer among mesorhizobia is thus suggested to direct their evolution and spatial pattern as reported for M. muleiense in China (Zhang et al. 2012a, b, 2020) and several Mesorhizobium species in Australia (Elias and Herridge 2015). Similarly, mesorhizobial strains nodulating shrub and tree legumes such as M. plurifarium (de Lajudie et al. 1998; Greenlon et al. 2019), M. shonense, M. hawassense and M. abyssinicae (Degefu et al. 2013) have been found to be closely related to chickpea strains (Tena et al. 2017) and may have shared symbiotic genes through horizontal gene transfer. Recent metagenomic analysis of DNA extracts from wild and cultivated chickpea root nodules has furthermore uncovered a large diversity of chickpea rhizobia (Greenlon et al. 2019) yet to be identified and evaluated for their potential differences in effective association with the host genotypes.

This newly found diversity of chickpea symbionts opens opportunities for the identification of superior strains to be used as inoculants. Although chickpea can fix up $60-80 \%$ of its required nitrogen (Giller 2001), actual symbiotic effectiveness is likely to differ between rhizobium strains $\left(\mathrm{G}_{\mathrm{R}}\right)$, legume genotypes $\left(\mathrm{G}_{\mathrm{L}}\right)$ as well as their combination $\left(\mathrm{G}_{\mathrm{L}} \times \mathrm{G}_{\mathrm{R}}\right)$ (Giller et al. 2013). There is surprisingly little literature on differential symbiotic effectiveness of diverse Mesorhizobium strains in chickpea, probably as a result of the crop's perceived symbiotic specificity. The few existing studies suggest that diverse Mesorhizobium strains can differ in symbiotic performance (Aouani et al. 1997, 2001; Ben Romdhane et al. 2008; Elias and Herridge 2015; Tena et al. 2016a), while others demonstrate differences in nitrogen fixation among chickpea cultivars (Beck 1992). The occurrence of so called $G_{L} \times G_{R}$ interaction in chickpea is even less well studied, with apparently only a single published study that used two unidentified strains and eight crop varieties to show some evidence of interaction (Beck 1992). This is unfortunate, since knowing the extent to which genetically diverse strains and cultivars may behave as symbiotic partners is of practical relevance for inoculant development. If $G_{L} \times G_{R}$ interaction occurs, it means that different elite strains may need to be developed for different legume varieties while if it does not, superior strains of broad applicability may be identified. There is reason to suspect that $G_{L} \times G_{R}$ interaction may be important in chickpea. It has been shown recently that chickpea stringently selects the symbiotic gene background (Zhang et al. 2012b), possibly playing a role in selecting symbiotic partners based on their effectiveness. In terms of the contribution of crop genetic variation, areas high of chickpea cultivar diversity such as Ethiopia (Anbessa and Bejiga 2002; Keneni et al. $2012 b$ ), further increased by the introduction of improved genotypes (Keneni et al. 2012a, b), have potential for a wide variation in symbiotic effectiveness and specificity. Apart from interactions due to individual cultivars, higher level genetic differences may also be of relevance. Cultivated chickpea genotypes are grouped based on seed size into Desi and Kabuli types (genepools). The large seeded Kabuli genotypes are said to fix more nitrogen than Desi genotypes in fertile soils while the reverse is true in marginal soils (Imran et al. 2015). Kabuli and Desi varieties responded differently to application of starter $\mathrm{N}$ and $\mathrm{P}$ fertilisers (Walley et al. 2005) which potentially relates to differences in regulation of $\mathrm{N}_{2}$ fixation (Walley et al. 2005). A distinct effect of genepool on symbiont selection has been reported in common bean, where Mesoamerican and Andean genepools were found to be exclusively nodulated by strains from their host region (Aguilar et al. 2004). Recent biogeographic studies have shown that regional genetic structure is also observed in chickpea mesorhizobia (Zhang et al. 2012b, 2020).

Here, we use a diversified set of chickpea accessions and Mesorhizobium strains and chickpea accessions, chosen to broadly represent the genetic diversity present in both taxa, to study the occurrence of $G_{L} \times G_{R}$ interaction. We examined whether interaction at the level of individual genotypes and strains occurs, whether larger scale patterns due to genepool may be discerned and whether such interactions are stable across experiments. We aimed to establish if there is likely to be potential for improving the yield of chickpea by matching cultivars to specific Mesorhizobium strains or conversely, if universally superior strains may be identified that hold promise for improved chickpea inoculants.

\section{Materials and methods}

\subsection{Genotypes and strains}

Chickpea genotypes (Table 1) were selected from previously described accessions using simple sequence repeat (SSR) markers (Updhayaya, unpublished). The accessions were assigned to 19 genetic groups using ward clustering based on the Euclidean distance matrix (van Heerwaarden et al. 2011) and the genetic distance between groups was calculated as the pairwise fixation coefficient (Weir and Cockerham 1984). Two genotypes per genetic group were selected by 
Table 1 Chickpea genotypes used in $\mathrm{G}_{\mathrm{L}} \times \mathrm{G}_{\mathrm{R}}$ interaction

\begin{tabular}{lllllll}
\hline No & Genotypes & Origin & Types & Genetic cluster & Jar & Pot \\
\hline 1 & ICC8621 & Ethiopia & Desi & 1 & $\sqrt{ }$ & X \\
2 & ICC12851 & Ethiopia & Desi & 3 & $\sqrt{ }$ & $\sqrt{ }$ \\
3 & ICC6263 & Russia & Kabuli & 11 & $\sqrt{ }$ & $\sqrt{ }$ \\
4 & ICC14098 & Ethiopia & Desi & 5 & $\sqrt{ }$ & X \\
5 & ICC5135 & India & Desi & 8 & $\sqrt{ }$ & X \\
6 & ICC13524 & Iran & Desi & 7 & $\sqrt{ }$ & $\sqrt{ }$ \\
7 & ICC4918 & India & Desi & 13 & $\sqrt{ }$ & $\sqrt{ }$ \\
8 & ICC15762 & SYR & Kabuli & 16 & $\sqrt{ }$ & X \\
9 & ICC3512 & Iran & Desi & 19 & $\sqrt{ }$ & X \\
10 & ICC7571 & Israel & Kabuli & 16 & $\sqrt{ }$ & X \\
11 & ICC13077 & India & Kabuli & 10 & $\sqrt{ }$ & X \\
12 & ICC9434 & Iran & Kabuli & 15 & $\sqrt{ }$ & $\sqrt{ }$ \\
13 & ICC13187 & Iran & Kabuli & 4 & $\sqrt{ }$ & X \\
\hline
\end{tabular}

Where " $"$ " = genotypes tested either in pots or jars; "X" = genotypes that were not tested in the pot experiment

considering their genepool proportion and imported from ICRISAT-India. A single genotype was randomly picked from each genetic group to fit them to our working space. Thirteen of the reselected genotypes ( 7 of which are Desi and 6 of which are Kabuli) were factorially combined with eleven mesorhizobial strains that consists of five reference strains imported from LMG rhizobial collection centre of Ghent University, Belgium and six local mesorhizobial strains (Table 2). The reference strains were selected based on previous reports of symbiotic associations with chickpea (Nour et al. 1995; Laranjo et al. 2004, 2008; Alexandre et al. 2006, 2009; Rivas et al. 2007), while the local strains were selected based on site of isolation and symbiotic effectiveness.
Subsequently, the local strains were phylogenetically characterized following the protocols we adopted previously (Gunnabo et al. 2019). Accordingly, partial 16S rRNA, gyr $B, r e c A$ and $r p o B$ housekeeping genes and symbiotic genes nifH and nodC were directly amplified from colony suspensions using a PCR (Bio-Rad Company). Additionally, a partial gene of $a t p D$ was amplified using primers atpDf (273-294 target gene position): 5'- SCT GGG SCG YAT CMT GAA CGT-3' and atpDr (748-771 target gene position): 5'- GCC GAC ACT TCC GAA CCN GCC TG-3' with the same PCR conditions used for $g y r B$ and $r p o B$ genes. For all the PCR reactions, PCR master mix was prepared by gently mixing 17.4 $\mu \mathrm{l} \mathrm{MQ}$ (Milli-Q or 'ultrapure') water, $2.5 \mu \mathrm{l}(10 \mathrm{x}$ ) Dream Taq buffer, $1 \mu \mathrm{l}(10 \mathrm{mM}$ each forward and reverse primers) and $0.1 \mu \mathrm{l}(5 \mathrm{U} / \mu \mathrm{l})$ Dream Taq DNA polymerase enzyme (Thermo Fischer Scientific Inc.). $23 \mu$ of the master mix was dispensed to PCR tubes to which $2 \mu l$ of the rhizobial colony suspension was added as a DNA templet and amplified. The PCR products were cleaned using Thermo-scientific PCR product cleaning kit and sequenced by Macrogen Inc. (the Netherlands).

\subsection{Phylogenetic analysis}

The quality of the DNA sequences was checked and edited by BioEdit Sequence Alignment Editor. The edited sequences were compared to GenBank database using the online nucleotide BLAST method (https://blast.ncbi.nlm.nih.gov/) to check if the right gene is sequenced and to which Mesorhizobium species it belongs. Multiple nucleotide sequence alignments were carried out using the CLUSTAL $\mathrm{W}$ program and concatenated in R 3.6.1 as we described previously (Gunnabo et al. 2019). The estimates of the bestfit models under maximum likelihood (ML) criterion for
Table 2 List of Rhizobium strains tested in $G_{L} \times G_{R}$ experiments

\begin{tabular}{lllllll}
\hline Rhizobium strains & Code & Origin & Host plant & References & Jar & Pot \\
\hline M. ciceri (UPM-Ca7) & LMG 14989 & Spain & C. arietinum & Nour et al. 1995 & $\sqrt{ }$ & $\sqrt{ }$ \\
M. mediterraneum (UPM-Ca36) & LMG17148 & Spain & C. arietinum & Nour et al. 1995 & $\sqrt{ }$ & $\sqrt{ }$ \\
M. tianshanense (CCBAU 3306) & LMG18976 & China & - & Chen et al. 1995 & $\sqrt{ }$ & X \\
M. amorphae (CCBAU 01583) & LMG18977 & China & A. fruticosa & Wang et al. & $\sqrt{ }$ & X \\
& & & & 1999 & & \\
M. haukuii (IAM 14148) & LMG14107 & China & A. sinicus & Chen et al. 1991 & $\sqrt{ }$ & X \\
CA10 & CA10 & Ethiopia & C. arietinum & HwU & $\sqrt{ }$ & $\sqrt{ }$ \\
CPJ1 & CPJ1 & Ethiopia & C. arietinum & HwU & $\sqrt{ }$ & X \\
CP129 & CP129 & Ethiopia & C. arietinum & HwH & $\sqrt{ }$ & X \\
CP130 & CP130 & Ethiopia & C. arietinum & Tena et al. 2017 & $\sqrt{ }$ & $\sqrt{ }$ \\
ACRS4b & ACRS4b & Ethiopia & C. arietinum & HwU & $\sqrt{ }$ & $\sqrt{ }$ \\
ACRS20a & ACRS20a & Ethiopia & C. arietinum & HwU & $\sqrt{ }$ & $\sqrt{ }$ \\
\hline
\end{tabular}

Where: HwU is Hawassa University; C. = Cicer; A. fruticosa = Amorpha fruticosa; A. sinicus = Astragalus sinicus; " $"$ " = strains tested either in pots or jars; "X" strains that were not tested in the pot experiment 
concatenated sequences (16S rRNA, atpD, gyrB, recA, rpoB) and symbiotic genes (nodC and nifH) was carried out in MEGA X (Kumar et al. 2016, 2018) and the substitution models with lower BIC (Bayesian information criterion) and $A I C c$ (Akaike information criterion corrected) values were selected for further reconstruction of the respective phylogenetic trees. Accordingly, phylogenetic tree of the concatenated housekeeping genes was reconstructed using General Time Reversible (GTR) Model with Gama distribution $(+\mathrm{G})$ and invariants among sites (+I) under Maximum Likelihood method in R using ape package. The robustness of the tree topology was calculated from bootstrap analysis with 500 replications of the sequences for Maximum Likelihood. The nodC phylogeny was reconstructed using Tamura 3-Parametr (T92) model (Tamura 1992) $+\mathrm{G}+\mathrm{I}$ and nifH was reconstructed using $\mathrm{T} 92+\mathrm{G}$ with 1000 bootstrap analysis under the maximum likelihood criterion. The percentage similarity of the genes was estimated using BioEdit software.

\section{3 $G_{L} \times G_{R}$ interactions in modified Leonard jars}

The first $G_{L} \times G_{R}$ interaction experiment $\left(13 G_{L} \times 11 G_{R}\right)$ was carried out in modified Leonard Jars containing river sand as growth medium in a greenhouse with optimum plant growth conditions (12-h light and $27-30{ }^{\circ} \mathrm{C}$ temperature). The Leonard jars and sand were prepared following standard protocols (Somasegaran and Hoben, 1994; Howieson and Dilworth 2016). Seeds of the selected chickpea genotypes were surface sterilized using $96 \%$ ethanol and $4 \%$ sodium hypochlorite and pregerminated in Petri Dishes containing sterile tissue paper (Somasegaran and Hoben 1994). The pregerminated seeds were aseptically transplanted into the jars. The selected strains were grown in yeast extract mannitol broth (YMB) medium in a rotary shaker at 130 revolution per minute (Somasegaran and Hoben 1994). In a factorial combination, $1 \mathrm{ml}$ of the selected rhizobial broth culture $\left(\sim 10^{9}\right.$ cell $\left.\mathrm{ml}^{-1}\right)$ was inoculated to the base of the seedlings growing in Leonard jars and rearranged in a completely randomized block design (RCBD). Each of the treatment units including positive (uninoculated but $\mathrm{N}$-fertilized with $0.5 \mathrm{mg} \mathrm{ml}^{-1} \mathrm{KNO}_{3}$ ) and negative (uninoculated and unfertilized) controls were replicated five times (except for Kabuli seed types that included 2-5 replications due the germination and survival problems) and supplemented with about $300 \mathrm{ml}$ Jensen's $\mathrm{N}$-free nutrient solution once in a week (Somasegaran and Hoben 1994). Meanwhile, deionized and sterile water was supplemented to the seedlings as needed. After growing the plants for 45 days in the greenhouse, they were harvested and assessed for nodulation and effectiveness (here, two Kabuli genotypes were rejected for which only a single replicate was survived in the jars).

The phenotypic responses of the interaction were recorded as nod+/nod- for presence and absence of nodules and fix + / fix- for symbiotic nitrogen fixation as determined by inspecting the internal colour of the nodules. Nodules with pink or red internal colours were recorded as "fixt", indicating effective symbiotic nitrogen fixation and nodules with green or white internal colours were recorded as "fix-", indicating ineffective symbiotic nitrogen fixation. Shoot biomass of the plants was also measured and analysed for elven genotypes (two Kabuli types excluded). Kabuli genotypes with at least two replicates were subjected to phenotypic analysis along with Desi genotypes from the jar experiment, from which a subset of two Kabuli (with three replications) and three Desi (with five replications) were selected for further analysis. The genotypes and strains included in the subset analysis were also forwarded for the pot experiment.

\section{$2.4 G_{L} \times G_{R}$ interaction in pots}

In the second $G_{L} \times G_{R}$ interaction experiment $\left(5 G_{L} \times 6 G_{R}\right)$, rhizobium and chickpea genotypes with positive nodulation and nitrogen fixation phenotypes were selected from the first interaction experiment. Since there was germination problem of Kabuli genotypes in the jar experiment as indicated above, some of the genotypes were rejected and only those that had at least three successful replications (subset of genotypes) were considered. The selected genotypes and strains (Tables 1 and 2) and their factorial combinations along with positive and negative controls (as described above) were tested in a pot experiment following the same protocols and growth conditions described in our previous work (Gunnabo et al. 2019).

\subsection{Estimating nitrogen derived from atmosphere (Ndfa)}

Plant total nitrogen was analyzed using near-infrared spectroscopy (NIRS) method at Nutrition Lab at International Livestock Research Institute (ILRI), Ethiopia. For NIRS analysis, the plant tissue samples were oven dried at $70{ }^{\circ} \mathrm{C}$ for $48 \mathrm{~h}$ and powdered using a mortar and pestel to pass through a $1 \mathrm{~mm}$ mesh. The mortar and pestel were cleaned with ethanol after each sample to avoid cross contamination. The prepared samples were again oven dried at $40{ }^{\circ} \mathrm{C}$ for overnight before scanning the samples using automated NIRS machine. While scanning one sample, the other samples were kept in a desiccator containing dried silica gel.

Ten percent of the samples were purposely selected by considering all the genotypes and subjected to wet-chemistry to determine plant total nitrogen and used to calibrate the NIRS method. The $\% \mathrm{~N}$ derived from the atmosphere (\%Ndfa) was estimated using $\mathrm{N}$ difference method (Unkovich et al. 2008) using the uninoculated plants as controls. 
$\% \mathrm{Ndfa}=(($ legume plant $\mathrm{N})-($ non- $\mathrm{N} 2-$ fixing control plant $\mathrm{N}) /$

(legume plantN) $) \times 100$

Where plant $\mathrm{N}$ is derived from plant $\mathrm{DM}$ and $\% \mathrm{~N}$ :

Plant $\mathrm{N}=\frac{S D W \times \% \mathrm{~N}}{100} \times 1000$

Corrected shoot dry weight (CSDW).

The seed differences among chickpea genotypes was corrected by subtracting uninoculated shoot dry weight $\left(\mathrm{SDW}_{\mathrm{N}}\right)$ from inoculated shoot dry weights $\left(\mathrm{SDW}_{\mathrm{I}}\right)$ for that specific genotype (i.e. $\mathrm{CSDW}=\mathrm{SDW}_{\mathrm{I}}-\mathrm{SDW}_{\mathrm{N}}$ for the specific genotype).

\subsection{Statistical analysis}

The nodulation (nod+, nod-) and fixation (fix+, fix-) phenotypic observation scores for specific genotype-strain combinations were summed for each replication and means of each count returns were predicted for the combinations. The means were then scaled based on minimum and maximum counts of the observations per combination to plot and see the patterns of observed phenotypic scores. Finally, $G_{L} \times G_{R}$ matrices of mean scores of (nod \pm ) and fixation (fix \pm ) were visualised by heat-maps in $\mathrm{R}$.

The effects of genotype, strains and their interaction on the quantitative variables corrected dry weight and nitrogen derived from atmosphere (Ndfa), were estimated by fitting the following linear mixed model $(\mathrm{lmm})$ :

$Y=$ Genotype + Strain + Genotype $*$ Strain + Rep $_{-}+e_{-}$

Where, $Y$ is the response variable as determined by the main effects of Genotype and Strain and interaction. Rep and $e$ are a random replicate effect and residual error, respectively. Significance of fixed effects was tested by a type I ANOVA with Satterthwaite's approximation to the degrees of freedom as implemented in lmerTest package in $\mathrm{R}$ version 3.6.1. Model means for each $\mathrm{G}_{\mathrm{L}} \times \mathrm{G}_{\mathrm{R}}$ combination were calculated with the predictmeans function (package predictmeans).

Effects of groups of genotypes were modelled as:

$$
\begin{aligned}
Y= & \text { Group }+ \text { Strain }+ \text { Group*Strain }+ \text { Genotype } \\
& + \text { Genotype }_{-} \text {Strain }_{-}+\text {Rep }_{-}+e_{-}
\end{aligned}
$$

Where the random terms Genotype and Strain. Genotype are the genotype main effect and the genotype times strain interaction.

After establishing the existence of $G_{L} \times G_{R}$ interaction an additive main effect and multiplication interaction (AMMI) model was used to decompose the interaction into genotype and strain main effects and their interaction portions. AMMI is defined as powerful tool for practical analysis and interpretation of genotype by environment trials in breeding programs (Zobel et al. 1988; Yan et al. 2000; Gauch et al. 2008). Thus, it was employed to describe patterns of $G_{L} x$ $\mathrm{G}_{\mathrm{R}}$ in terms of $\mathrm{N}_{2}$-fixation and relative biomass.

AMMI subtracts the $\mathrm{G}$ and $\mathrm{E}$ main effects before singular value decomposition (SVD) and applies SVD to the GE term to decompose the $\mathrm{G}$ by E interaction effects (Zobel et al. 1988; Yan et al. 2000). That is how AMMI partitions the overall variation into $\mathrm{G}$ and $\mathrm{E}$ main and $\mathrm{GE}$ interaction effects (Hugh 2006). The advantage of AMMI analysis is that it gives direct insight into the contribution of genotypes and environments (or $G_{L}$ and $G_{R}$ in our case) to the interaction (Hugh 2006) and that it provides a more powerful description of the interaction by extracting patterns of $G_{L}$ and $G_{R}$ and minimising noise due to specific interactions due to single genotypes and strains. The AMMI model used is given by the equation (Frutos et al. 2013):

$$
\mathrm{Yij}=\mu+\alpha_{i}+\beta \mathrm{j}+\sum_{k=1}^{t} \lambda_{k} \xi_{i k} \eta_{k j}+\varepsilon_{i j}
$$

Where $\mu$ is the overall mean; $\alpha_{i}$ is the genotype main effect; $\beta_{\mathrm{j}}$ is the environment main effect; $t$ is the number of SVD axes retained in the model; $\lambda_{k}$ is the singular value for the SVD axis $k ; \xi_{i k}$ is the singular value of the genotype i for the SVD axis $k$; $\eta_{k j}$ is the singular value of the environment $\mathrm{j}$ for the SVD axis $\mathrm{k}$; and $\varepsilon_{i j}$ is the error term of the models. The AMMI analysis was performed using the "agricolae" package in R.

\section{Results}

\subsection{Phylogeny of selected rhizobial strains}

Phylogenies of 16S rRNA and multilocus gene sequence analysis (MLSA) (Fig. 1) revealed a wide genetic distribution of the local and reference strains. The 16S rRNA gene grouped all the local strains together with $M$. silamurunense CCBAU01550, M. shonense AC39a and M. hawassense AC99b at low bootstrap (BT) support, while the MLSA phylogeny grouped these strains into a well-supported clade with a $100 \%$ BT value. None of the reference strains $M$. amorphae LMG 18977, M. haukuii LMG14107, M. tianshanense LMG 18976, M. mediterraneum LMG 17148 and M. ciceri LMG 14989 clustered with any of the local strains in either the $16 \mathrm{~S}$ or MLSA phylogenies but were scattered throughout the tree in both cases, attesting to their genetic diversity. Bootstrap support was generally higher for in the MLSA phylogeny, owing to the larger number of informative sites.

By contrast, the symbiotic gene phylogenies grouped the local strains together with most of the previously reported chickpea nodulating type strains such as M. ciceri, $M$. meditteraneum, M. wenxiniae, M. haukuii and M. muleiense (Fig. 2) suggesting that the local Mesorhizobia 
Fig. 1 16S rRNA and MLSA phylogenies of Mesorhizobium strains. The phylogenetic trees were reconstructed using GTR + G + I method. The local test strains are represented by codes without scientific names while the test reference strains ware indicated by ' $*$ ' at the end of the strain codes
Fig. 2 Symbiotic gene phylogenies of mesorhizobia strains. Both phylogenies a nodC and $\mathbf{b}$ nifH were reconstructed using Kimura-2 parameter model with gamma distribution

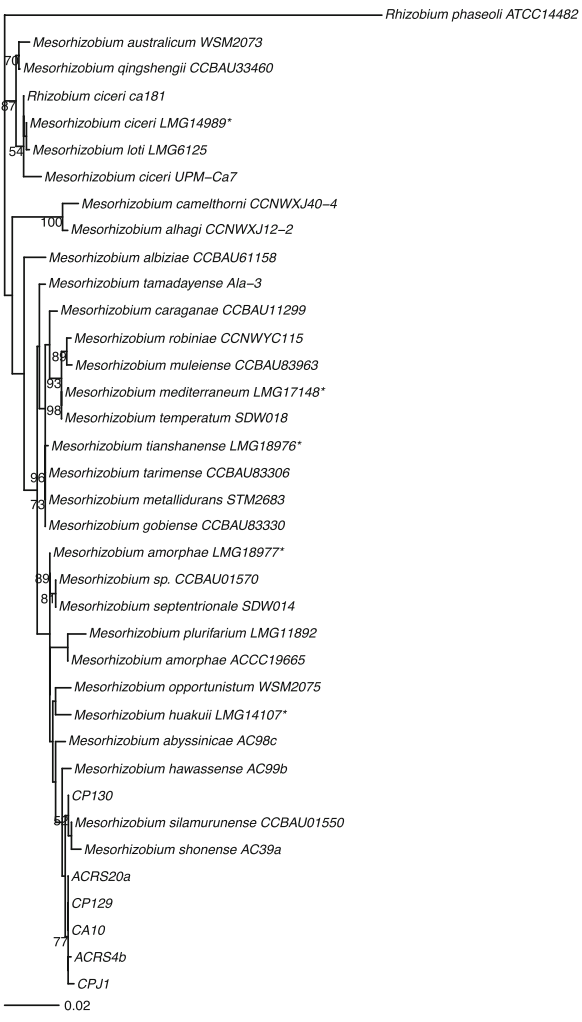

a) $16 \mathrm{~s}$

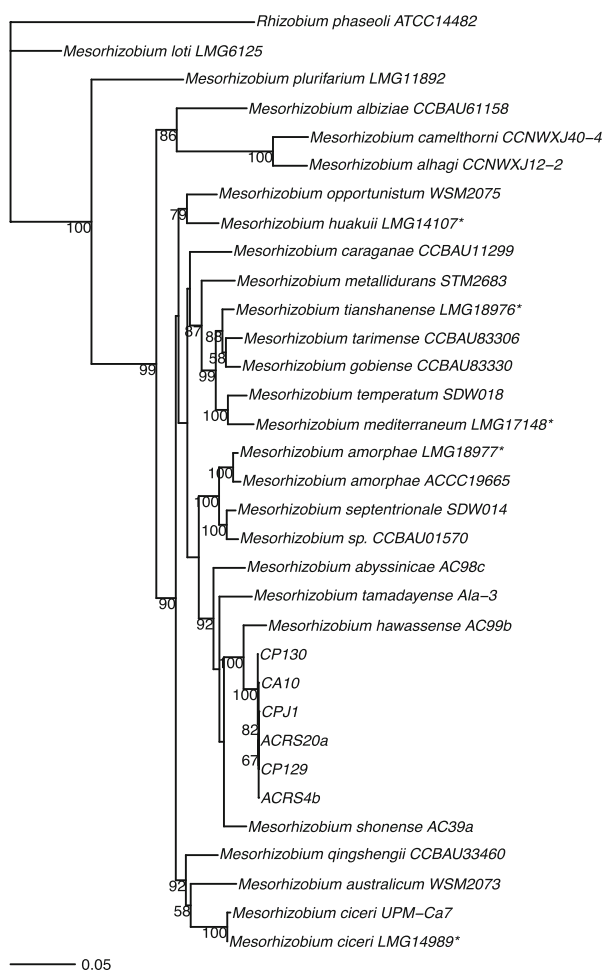

b) MLSA

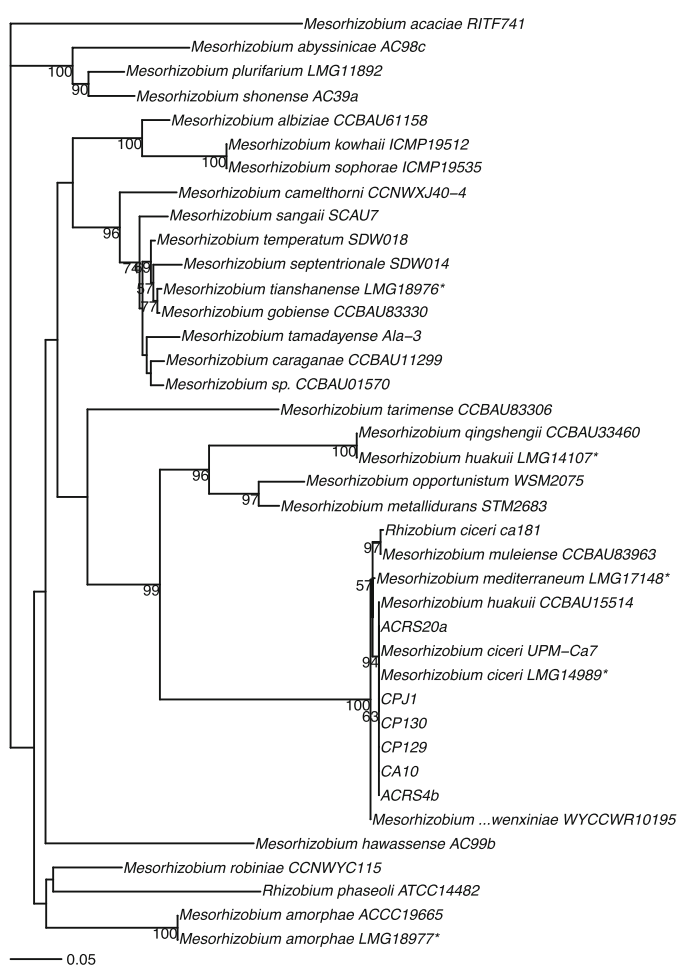

a) nodC

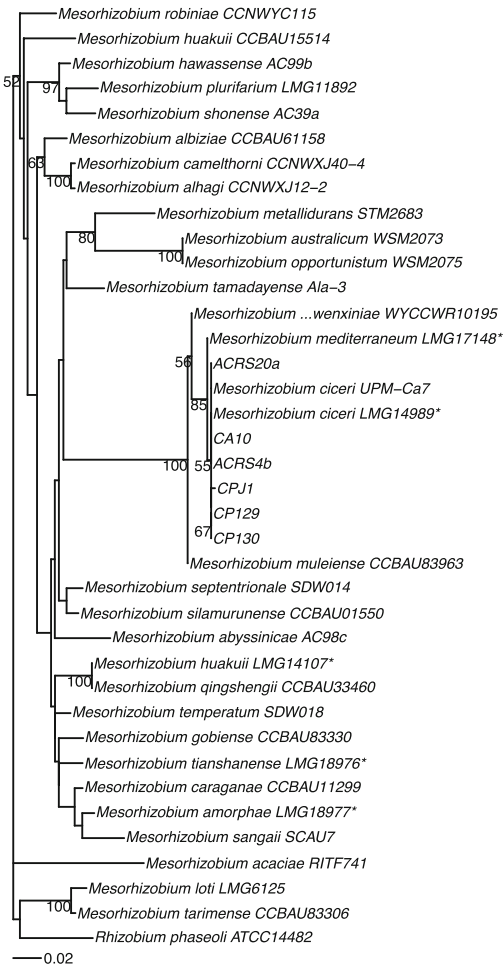

b) nifH 
share common symbiotic genes nodC and nifH with known effective strains. The strains $M$. silamurunense CCBAU01550, M. shonense AC39a and M. hawassense AC99b, with which the local strains clustered in MLSA, occupied quite different positions in symbiotic gene phylogenies. These strains were isolated from shrub or tree legumes (Zhao et al. 2012; Degefu et al. 2013) and might have obtained symbiotic genes from chickpea nodulating strains. Since they have different chromosomal background genes, their symbiotic $\mathrm{N}_{2}$-fixation potential might vary and could reveal genetic interactions with host genotypes. In general, the symbiotic and housekeeping gene phylogenies reflected good genetic representation of the local and reference strains that were used as test strains for our genetic interaction study.

\subsection{Occurrence of $G_{L} \times G_{R}$ interaction in chickpea}

$\mathrm{G}_{\mathrm{L}} \times \mathrm{G}_{\mathrm{R}}$ interaction in chickpea in terms of nodulation (nod \pm ), fixation (fix \pm ) and corrected shoot dry weight (CSDW) is shown in Fig. 3. Cells with orange, yellow and green colours refer to weak, medium and good symbiotic performance respectively. Kabuli genotypes in the jar experiment had several missing values due to poor seed germination and survival in jars, which meant that only 2 replications were considered for the overall analysis (Table 1) and 3 replications for the subset. This was represented with patches of orange and yellow patterns for nodulation and fixation in jars and jar subsets (Fig. 3a-f). In the jar experiment, strains $M$. tianshanense LMG $18976^{\mathrm{T}}$, M. haukuii LMG $14107^{\mathrm{T}}$ and M. amorphae LMG $18976^{\mathrm{T}}$ were able to induce nodules on some chickpea genotypes (some Desi genotypes), but not on the others (Fig. $3 \mathrm{a}, \mathrm{b}$ ), reflecting early specificity during infection. However, their shoot biomass did not differ from negative controls, plants that received no fertilizer and were not inoculated. Other strains showed consistent nodulation across the chickpea genotypes, but had various fixation and corrected shoot biomass, on the other hand, showing potential differences of strains after infection. In the pot experiment, germination problems of Kabuli genotypes were avoided by using newly multiplied seeds and increased number of replications that were used to replace missing ones. Strains that were effective in jar experiment were not consistently found effective in pots;

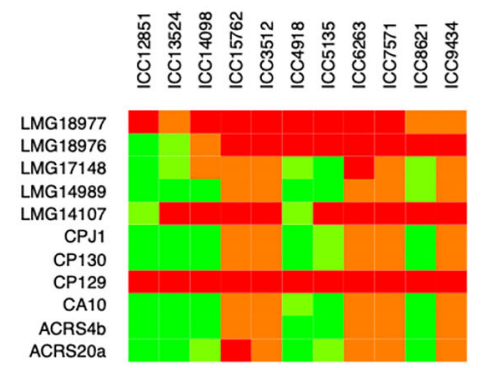

a) Nodulation in jars
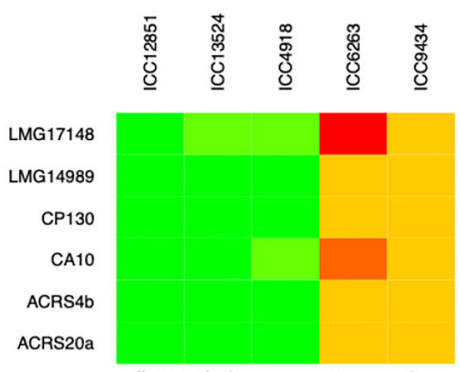

d) Nodulation in jars subset

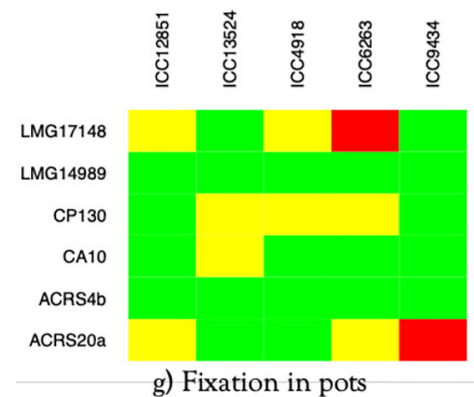

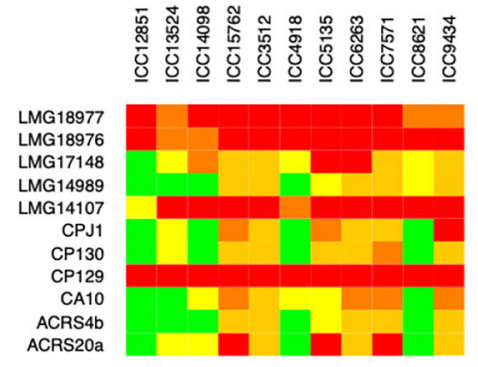

b) Fixation in jars
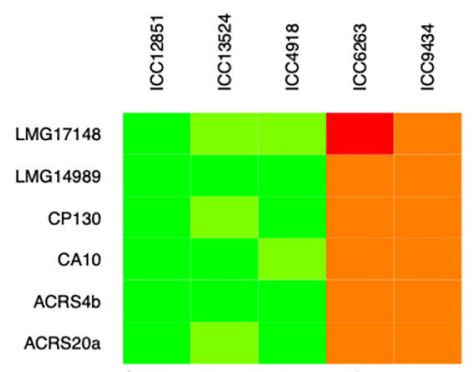

e) Fixation in jars subset
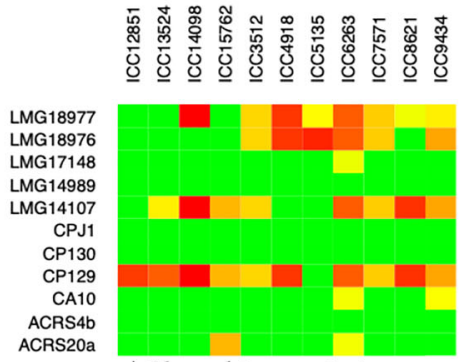

c) Shoot biomass in jars
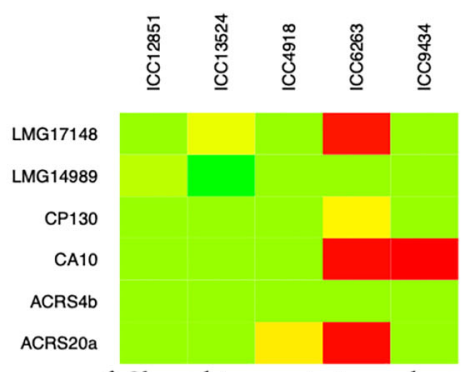

f) Shoot biomass in jars subset

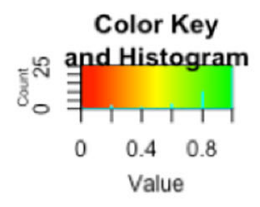

h) Shoot biomass in pots

Fig. $3 G_{L} \times G_{R}$ patterns of nodulation, fixation and corrected shoot biomass in jars and pots in chickpea. Colour key was adjusted based on minimum, mean, and maximum scores of nodulation, fixation, and relative shoot dry matter for each case 
i.e. interaction patterns were not consistent between jars and pots. There was $100 \%$ nodulation in pots (showing no variation and was removed from Fig. 3) but the $\mathrm{N}_{2}$ fixation outcomes did not correspond to nodulation status, reflecting that not all infections resulted in $\mathrm{N}_{2}$ fixation.

We observed a significant main effect of strain and a highly significant $\mathrm{G}_{\mathrm{L}} \times \mathrm{G}_{\mathrm{R}}$ interaction $(P<0.003366)$ in the jar experiment (Table 3 ). This interaction was caused by a single Kabuli genotype ICC6263; however, its removal from the analysis resulted in loss of significance. In the pot experiment, only a strain main effect was observed on plant dry matter and nitrogen derived from atmosphere ( $\mathrm{Ndfa}$ ). There were no main effects of genotype or interaction of genotype with strains. Overall, the chickpea genepools (Kabuli and Desi types) did not affect the genotype by strain interaction in either the jar or pot experiments.

Under both growing conditions, a reference strain $M$. ciceri LMG 14989 was the best across all the genotypes accumulating much higher shoot dry weight and fixing atmospheric nitrogen (Fig. 4a-c), except for genotypes ICC4918 and ICC6263 in jars, with which CP130 performed well. In fact, in both experiments LMG 14989 was the only strain with a biomass significantly higher than the control, reflecting both weak performance of other strains and large variation in the data.

\subsection{Patterns of the $G_{L} \times G_{R}$ interaction}

Having shown some degree of $G_{L} \times G_{R}$ interaction in chickpea (only seen in jars), we decomposed strain-genotype combination effects to identify potential interaction patterns and strains with stable and high performance. In the jar experiment, AMMI analysis revealed the first two principal components (PC1 and PC2) to be significant (Table 4), associated with superior performance of the combinations CP130ICC6263; LMG17148-ICC13524 and the local strains CA10 and ACSR20a with Desi genotypes ICC12851 and 4918, while LMG 14898 was a stable strain across genotypes in the jars (Fig. 5). In the pot experiment, none of the principal components were significant and the highly performed strain LMG 14989 was found stable across the genotypes (Fig. 5). An unstable response to M. mediterraneum LMG 17148, was found to account for majority of the variation in AMMI biplots both in terms of $\mathrm{N}_{2}$ fixation and shoot biomass. The genepool analysis did not show patterns in the interaction (Fig. S1). Similarly, symbiotic genes did not reflect patterns in symbiotic interaction as all the test strains share a single symbiotic gene.

\section{Discussion}

Chickpea was earlier believed to form symbioses with a restricted range of Mesorhizobium species that fix atmospheric nitrogen. Advancement in methods of molecular analysis led to the discovery that several more Mesorhizobium species can nodulate chickpea that show variation in symbiotic nitrogen fixation potential. To harvest sufficient nitrogen from atmosphere by symbiotic nitrogen fixation, identifying the best matches of Mesorhizobium sp. and chickpea genotypes is required. Screening for the best fitting symbiotic partners is recommended since significant host genotype $\mathrm{x}$ rhizobium strain interactions have been demonstrated in many legumes such as common bean (Hungria and Neves 1987; Epping et al. 1994; Montealegre and Kipe-Nolt 1994), Bambara groundnut (Somasegaran et al. 1990), lentil (Rai et al. 1985), pea (Laguerre et al. 2007), soybean (Devine and Kuykendall 1996), lotus (Regus et al. 2015), white clover (Mytton 1975), peanut (Wynne et al. 1983), Medicago (Heath et al. 2012) and Acacia (Barrett et al. 2015). The presence of a genotype $\left(\mathrm{G}_{\mathrm{L}}\right)$ x rhizobium genotype $\left(\mathrm{G}_{\mathrm{R}}\right)$ interaction was reported for chickpea using eight Kabuli cultivars and two unidentified strains (Beck 1992). The limited taxonomic scope and lack of strain information in the latter study means that it is unclear if patterns of symbiotic effectiveness are predictable.
Table 3 ANOVA table of mixed linear model for $\mathrm{G}_{\mathrm{L}} \times \mathrm{G}_{\mathrm{R}}$ interaction based on joint data

\begin{tabular}{lllllc}
\hline \multirow{2}{*}{ Source of variations } & DF & & Mean squares & \\
\cline { 3 - 5 } & & & $\mathrm{CSDW}_{(\mathrm{mg})}$ in jar & $\mathrm{CSDW}_{(\mathrm{mg})}$ in pot & $\mathrm{Ndfa}_{(\mathrm{mg})}$ in pot \\
\hline \multirow{2}{*}{ Genotypes } & $\mathrm{G}_{\mathrm{L}}$ & 4 & 0.012 & 0.005 & 26.82 \\
& $\mathrm{G}_{\mathrm{R}}$ & 5 & $0.046^{*}$ & $0.312^{* * *}$ & $361.85^{* * *}$ \\
& $\mathrm{G}_{\mathrm{L}}: \mathrm{G}_{\mathrm{R}}$ & 20 & $0.037^{* *}$ & 0.039 & 14.96 \\
Genepools & $\mathrm{G}_{\mathrm{P}}$ & 1 & 0.001 & 0.007 & 35.31 \\
& $\mathrm{G}_{\mathrm{R}}$ & 5 & 0.034 & $0.264^{*}$ & $316.74^{* *}$ \\
& $\mathrm{G}_{\mathrm{P}}: \mathrm{G}_{\mathrm{R}}$ & 5 & 0.022 & 0.014 & 11.91 \\
\hline
\end{tabular}

Where: $G_{L}=$ Legume genotype; $G_{R}=$ Rhizobium genotype; $G_{P}=$ genepool that categorizes genotypes as Kabuli and Desi groups; $\mathrm{CSDW}=$ corrected shoot dry weight in gram. Significance: ' $* * *$ ' for $P<0.001$; ' $* *$ ' for $P<0.01$; '*' for $P<0.05$; ' ' for $P<0.1$ 

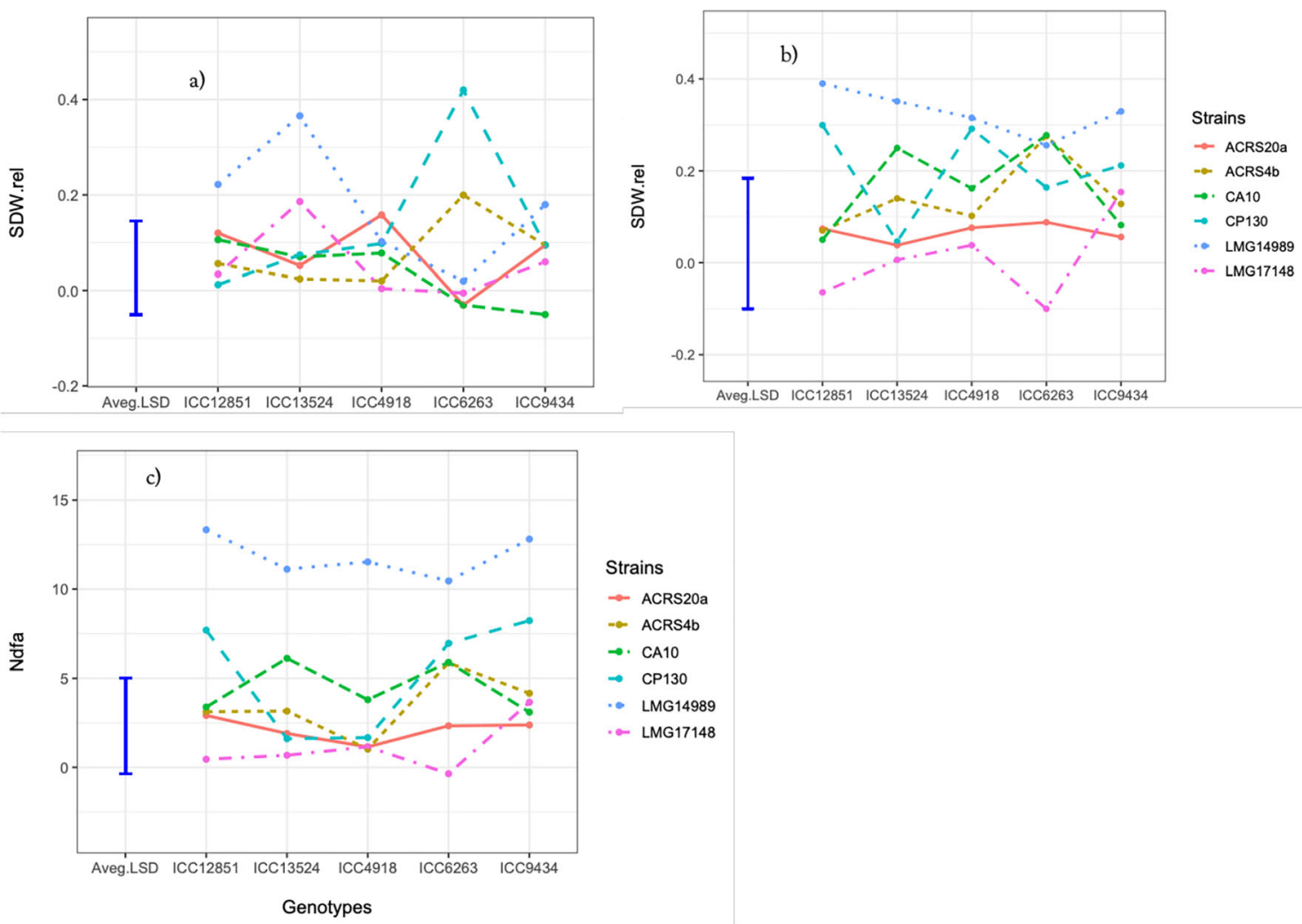

Fig. $4 \mathrm{G}_{\mathrm{L}} \times \mathrm{G}_{\mathrm{R}}$ interaction in chickpea in jars and pots. (a) Corrected relative shoot dry weight (SDW.rel; in grams) in jars; (b) SDW.rel in pots; (c) relative amount of nitrogen derived from atmosphere (Ndfa)

We assessed the occurrence of $G_{L} \times G_{R}$ in chickpea using a much wider genetic coverage of genotypes (including Kabuli and Desi types) and Mesorhizobium strains, taking advantage of the diversity of new symbionts that has been identified over the past decades, including some native to Ethiopia. The

Table 4 Contributions of AMMI principal components to the variations of $G_{L} \times G_{R}$ interaction in chickpea

\begin{tabular}{|c|c|c|c|c|c|c|}
\hline \multirow[t]{2}{*}{ GE } & \multirow[t]{2}{*}{ PCs } & \multirow[t]{2}{*}{ Df } & \multicolumn{2}{|l|}{ SDW } & \multicolumn{2}{|l|}{ Ndfa } \\
\hline & & & Percent & MS & Percent & MS \\
\hline \multirow[t]{4}{*}{ Jar } & PC1 & 8 & 69.1 & $2.64 * * *$ & & \\
\hline & $\mathrm{PC} 2$ & 6 & 25.1 & $1.24 *$ & & \\
\hline & PC3 & 4 & 3.8 & 0.29 & & \\
\hline & PC4 & 2 & 2.0 & 0.30 & & \\
\hline \multirow[t]{4}{*}{ Pot } & PC1 & 8 & 61.1 & 0.97 & 59.1 & 0.70 \\
\hline & $\mathrm{PC} 2$ & 6 & 26.1 & 0.55 & 33.1 & 0.52 \\
\hline & PC3 & 4 & 9.7 & 0.31 & 7.8 & 0.18 \\
\hline & PC4 & 2 & 3.0 & 0.19 & 0.0 & 0.002 \\
\hline
\end{tabular}

Where, $G E$ growth environment, $P C$ principal components, $S D W$ shoot dry weight, $N N$ Nodule number, $N D W$ Nodule dry weight, $N d f a$ nitrogen derived from the atmosphere, $M S$ mean squares. Significance: '***' for $P<0.001$; ‘**' for $P<0.01$; '*' for $P<0.05$; '. ' for $P<0.1$ demonstrated ability of local strains to obtain symbiotic genes from the chickpea natural microsymbionts by horizontal gene transfer implies that the ability to form symbiosis with chickpea may be distributed across very diverse genetic backgrounds. The question whether stable $\mathrm{G}_{\mathrm{L}} \times \mathrm{G}_{\mathrm{R}}$ interactions exist is of direct relevance for determining the potential for improving inoculant performance by matching Mesorhizobium strains to specific cultivars or cultivar types (Rodríguez-Navarro et al. 1999)?

Prior to the $\mathrm{G}_{\mathrm{L}} \times \mathrm{G}_{\mathrm{R}}$ interaction study, we performed phylogenetic analysis of the local and reference strains that revealed wide genetic diversity of Mesorhizobium species. The 16S rRNA gene related the local strains with Mesorhizobium strains such as $M$. silamurunense, M. shonense and $M$. hawassense that nodulate tree or shrub legumes, while MLSA tightly assigned them with $M$. hawassense. The strain $M$. silamurunense was previously reported to be closely related to M. plurifarium LMG11892 ${ }^{\mathrm{T}}$ (Zhao et al. 2012) a species that clustered with strains of $M$. abyssinicae, M. shonense and M. hawassense (Tena et al. 2017). The latter strains are tree legume nodulating ones identified from Ethiopia (Degefu et al. 2013) and were previously shown to have similar core genes with strains nodulating chickpea grown in the country (Tena et al. 2017). On the other hand, the symbiotic genes related them with the known chickpea nodulating strains 
Fig. 5 AMMI biplots of corrected shoot dry weights in jars and nitrogen fixation in pots a) SDW in Jars

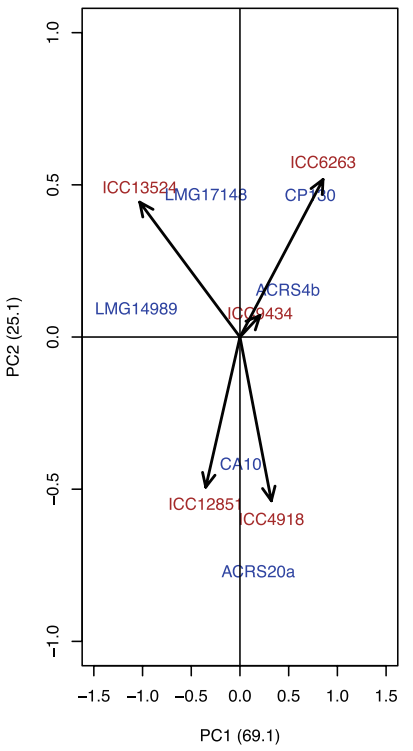

b) SDW in Pots

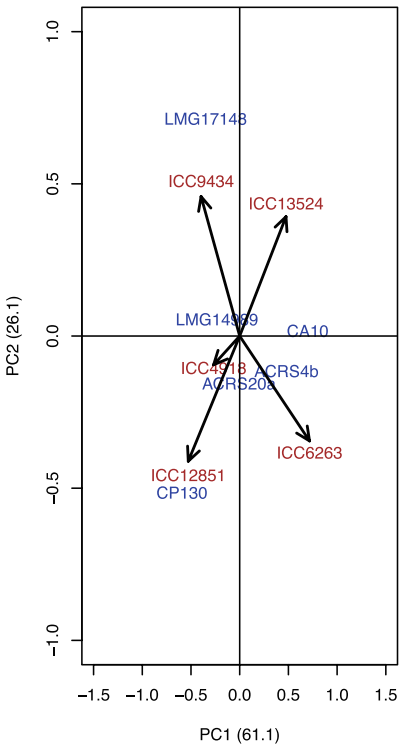

c) Ndfa in pots

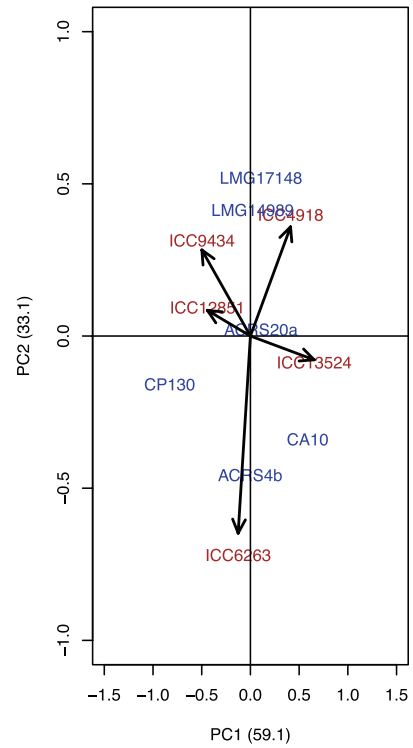

M. ciceri, M. mediterraneum, M. wenxiniae and M. muleiense, reflecting that all chickpea nodulating strains share a common symbiotic gene as a result of gene exchange horizontally (Zhang et al. 2020). Because the symbiotic (accessary) genes often show horizontal gene transfer between Mesorhizobium strains (Laranjo et al. 2014; Lindström et al. 2015; Elias and Herridge 2015), whose effect is proposed to direct the genetic evolution and biogeographic patterns in mesorhizobia (Zhang et al. 2020). The horizontal gene transfer among the current and the previous mesorhizobia reported by Tena et al. (2017) agrees with the genetic exchange observed in mesorhizobia from China and Australia (Elias and Herridge 2015; Zhang et al. 2020). This genetic exchange among mesorhizobia was also shown elsewhere (Nandasena et al. 2007, 2009; Elias 2009; Zhang et al. 2012b, 2014; Elias and Herridge 2015), where the introduced chickpea plants have been proposed to selectively associate with some novel rhizobia adapted to local conditions (Zhang et al. 2020). The mobility of the symbiotic genes between different species thus reflects their crossinoculation (host range) groups, rather than determining their species affiliation (Laranjo et al. 2014). In our case, the probable transfer of chickpea-compatible symbiotic genes to diverse genospecies including mesorhizobia native to Ethiopia meant that our selection of strains was highly diverse, including genetically distinct genospecies belonging to the classic chickpea symbiovars as well as those containing divergent symbiotic genes.

We found some evidence for the presence of a $G_{L} \times G_{R}$ interaction in chickpea in the jar experiment but this was driven entirely by the presence of a single Kabuli genotype ICC6263. In fact, the follow-up experiment in pots only showed a main effect of strain that basically reflected the superior performance of the $M$. ciceri type strain LMG 14989, which across the two experiments was the only strain with significant average biomass production over the negative control and was found to be superior in terms of nodulation, nitrogen fixation and plant dry matter. This result may correspond to the fact that chickpea has specific rhizobial requirement (Gaur and Sen 1979), as indicated with a single cluster of symbiotic-related gene phylogeny (Tena et al. 2017) but the fact that other strains sharing the same symbiotic genes performed poorly in our study shows that chickpea may be restrictive in terms of genetic backgrounds with which it will form effective symbiosis. The poor performance of these local strains could be related to the fact that they were originally tree legume symbionts, as indicated by the $16 \mathrm{~S}$ rRNA and MLSA phylogenies.

Some rhizobial strains failed to induce nodules in many cases despite having been identified as effective symbionts in earlier studies. For instance, strains M. haukuii LMG $14107^{\mathrm{T}}$ isolated from Astragalus sinicus (Chen et al. 1991), M. tianshanense LMG $18976^{\mathrm{T}}$ isolated from Amorpha fruticosa and M. amorphae LMG $18977^{\mathrm{T}}$ isolated from Glycyrrhiza pallidiflora (Rivas et al. 2007), were previously reported to nodulate chickpea and to have similar symbiotic genes with the natural microsymbionts of the chickpea (Chen et al. 1991, 1995; Wang et al. 1999; Rivas et al. 2007; Alexandre et al. 2009), both contradicted by our results. This indicates that the strains used in previous studies are symbiovars of ciceri but that the type strains used here do not share the required symbiotic genes. Their erratic nodulation of chickpea genotypes may reveal the first level specificity of interaction that could be controlled by some symbiotic genes (like 
host gene sym 2 and rhizobium gene $\operatorname{nod} X)$ as we discussed elsewhere (Gunnabo et al. 2019).

The $\mathrm{G}_{\mathrm{L}} \times \mathrm{G}_{\mathrm{R}}$ interaction detected in jars did not reflect any effects of genepool, which was found to have no interaction with strain, similar to what we reported earlier for common bean (Gunnabo et al. 2019). The AMMI analysis thus showed that $70 \%$ of the interaction variation in jars was explained by the first principal component. Specifically, strains CA10 and ACRS20a positively combined with ICC12851 and ICC4918, respectively and negatively combined with ICC13524 and ICC6263, respectively (Fig. 5). This analysis also confirmed the stable performance of LMG 14989.

We found that the $G_{L} \times G_{R}$ interaction observed in jars was not repeated in our pot experiment. This suggests that expression of $G_{L} \times G_{R}$ may depend on the growth environment, similar to results obtained in common bean (Gunnabo et al. 2019). Such an effect is consistent with the fact that naturally occurring rhizobium strains vary in how much nitrogen they fix on a given host genotype and differ across multiple host genotypes or species depending on the environment (Mytton 1975; Gibson et al. 1999; Heath and Tiffin 2007). Previous reports have indicated strain performance differences both under controlled and field conditions (Tena et al. 2016a, b), but these authors found a strain $\mathrm{x}$ cultivar interaction only in one field experiment. We also observed differences in genotype performance in the different growth environments. Comparatively, Kabuli genotypes performed well in pot experiment while the Desi ones were better in Jars, confirming that Kabuli genotypes need better condition for better symbiotic performance (Imran et al. 2015). Based on our results, we recommend using large growth volumes for initial screening combined with confirmatory field experiments prior to further advancement of strains.

\section{Conclusions}

A phylogenetically broad genetic composition of reference and local Mesorhizobium strains were studied in combination with diverse chickpea cultivars. Although we found some evidence of $G_{L} \times G_{R}$ interaction in our jar experiment, this was due to a single genotype and could not be repeated in a followup experiment in pots, suggesting that the growth environment may affect the outcome of effectiveness screening. This suggests that care must be taken when evaluating strain $\mathrm{x}$ host genotype interactions under greenhouse conditions and that repeated field experiments should be performed before making practical recommendations.

Our main result is that the well-known chickpea symbiont M. ciceri, LMG 14989 was superior across all genotypes and in both experiments. The fact that local strains shared the same symbiotic genes but were found to have poor performance shows that gaining the ability to infect chickpea is not a guarantee of effectiveness. It therefore seems that investing in the identification of superior strains may pay higher dividends than searching for specialised inoculants for different cultivars.

Acknowledgements We thank the Bill \& Melinda Gates Foundation for partnering in this research through a grant to Wageningen University to support the project N2Africa: Putting Nitrogen Fixation to Work for Smallholder Farmers in Africa (www.N2Africa.org).

Open Access This article is licensed under a Creative Commons Attribution 4.0 International License, which permits use, sharing, adaptation, distribution and reproduction in any medium or format, as long as you give appropriate credit to the original author(s) and the source, provide a link to the Creative Commons licence, and indicate if changes were made. The images or other third party material in this article are included in the article's Creative Commons licence, unless indicated otherwise in a credit line to the material. If material is not included in the article's Creative Commons licence and your intended use is not permitted by statutory regulation or exceeds the permitted use, you will need to obtain permission directly from the copyright holder. To view a copy of this licence, visit http://creativecommons.org/licenses/by/4.0/.

\section{References}

Aguilar OM, Riva O, Peltzer E (2004) Analysis of rhizobium etli and of its symbiosis with wild Phaseolus vulgaris supports coevolution in centers of host diversification. PNAS 101:13548-13553. https://doi. org/10.1073/pnas.0405321101

Alexandre A, Laranjo M, Oliveira S (2006) Natural populations of chickpea rhizobia evaluated by antibiotic resistance profiles and molecular methods. Microb Ecol 51:128-136. https://doi.org/10.1007/ s00248-005-0085-3

Alexandre A, Brígido C, Laranjo M, Rodrigues S, Oliveira S (2009) Survey of chickpea rhizobia diversity in Portugal reveals the predominance of species distinct from Mesorhizobium ciceri and Mesorhizobium mediterraneum. Microb Ecol 58:930-941. https:// doi.org/10.1007/s00248-009-9536-6

Anbessa Y, Bejiga G (2002) Evaluation of Ethiopian chickpea landraces for tolerance to drought. Genet Resour Crop Evol 49:557-564. https://doi.org/10.1023/A:1021210601480

Aouani ME, Mhamdi R, Mars M, Elayeb M, Ghtir R (1997) Potential for inoculation of common bean by effective rhizobia in Tunisian soils. Agronomie 17:445-454. https://doi.org/10.1051/agro:19970902

Aouani M, Mhamdi R, Jebara M et al (2001) Characterization of rhizobia nodulating chickpea in Tunisia. Agron EDP Sci 21:577-581. https:// doi.org/10.1051/agro:2001147

Armas-Capote N, Pérez-Yépez J, Martínez-Hidalgo P, Garzón-Machado V, del Arco-Aguilar M, Velázquez E, León-Barrios M (2014) Core and symbiotic genes reveal nine Mesorhizobium genospecies and three symbiotic lineages among the rhizobia nodulating Cicer canariense in its natural habitat (La Palma, Canary Islands). Syst Appl Microbiol 37:140-148. https://doi.org/10.1016/j.syapm.2013. 08.004

Barrett LG, Bever JD, Bissett A, Thrall PH (2015) Partner diversity and identity impacts on plant productivity in Acacia-rhizobial interactions. J Ecol 103:130-142. https://doi.org/10.1111/1365-2745. 12336

Beck DP (1992) Yield and nitrogen fixation of chickpea cultivars in response to inoculation with selected rhizobial strains. Agron J 84: 
510-516. https://doi.org/10.2134/agronj 1992 . $00021962008400030029 x$

Ben Romdhane S, Aouani ME, Trabelsi M, de Lajudie P, Mhamdi R (2008) Selection of high nitrogen-fixing rhizobia nodulating chickpea (Cicer arietinum) for semi-arid Tunisia. J Agron Crop Sci 194: 413-420. https://doi.org/10.1111/j.1439-037X.2008.00328.x

Chen WX, Li G, Qi Y et al (1991) Rhizobium huakuii sp. nov. isolated from the root nodules of Astragalus sinicus. Int J Syst Bacteriol 41: 275-280. https://doi.org/10.1099/00207713-41-2-275

Chen W, Wang E, Wang S et al (1995) Characteristics of rhizobium tianshanense sp. nov., a moderately and slowly growing root nodule bacterium isolated from an arid saline environment in Xinjiang, People's Republic of China. Int J Syst Bacteriol 45:153-159. https://doi.org/10.1099/00207713-45-1-153

de Lajudie P, Willems A, Nick G, Moreira F, Molouba F, Hoste B, Torck U, Neyra M, Collins MD, Lindstrom K, Dreyfus B, Gillis M (1998) Characterization of tropical tree rhizobia and description of Mesorhizobium plurifarium sp. nov. Int J Syst Bacteriol 48:369382. https://doi.org/10.1099/00207713-48-2-369

Degefu T, Wolde-meskel E, Liu B, Cleenwerck I, Willems A, Frostegård $\AA$ (2013) Mesorhizobium shonense sp. nov., Mesorhizobium hawassense sp. nov. and Mesorhizobium abyssinicae sp. nov., isolated from root nodules of different agroforestry legume trees. Int J Syst Evol Microbiol 63:1746-1753. https://doi.org/10.1099/ijs.0. 044032-0

Devine TE, Kuykendall LD (1996) Host genetic control of symbiosis in soybean (Glycine max 1.). Plant Soil 186:173-187. https://doi.org/ 10.1007/BF00035072

Elias N (2009) Optimizing nodulation in chickpea for nitrogen fixation and yield in the northern grains belt of NSW. The University of Western Sydney

Elias NV, Herridge DF (2015) Naturalised populations of mesorhizobia in chickpea (Cicer arietinum L.) cropping soils: effects on nodule occupancy and productivity of commercial chickpea. Plant Soil 387: 233-249. https://doi.org/10.1007/s11104-014-2298-z

Engels JMM, Hawkes JG (1991) The Ethiopian gene centre and its genetic diversity. In: Engels JMM, Hawkes JG, Worede M (eds) Plant genetic resources of Ethiopia. Cambridge Unversity Press, Cambridge, p 397

Epping B, Hansen AP, Djalali B, Martin P (1994) Symbiotic effectivity of four phaseolus vulgaris genotypes after inoculation with different strains of rhizobium under controlled conditions. Z Naturforsch $49 \mathrm{c}: 343-351$

Frutos E, Galindo MP, Leiva V (2013) An interactive biplot implementation in $\mathrm{R}$ for modeling genotype-by-environment interaction. Stoch Environ Res Risk Assess 28:1629-1641. https://doi.org/10. 1007/s00477-013-0821-z

Gauch HG, Piepho HP, Annicchiarico P (2008) Statistical analysis of yield trials by AMMI and GGE: further considerations. Crop Sci 48:866-889. https://doi.org/10.2135/cropsci2007.09.0513

Gaur Y, Sen AN (1979) Cross inoculation group specificity in CicerRhizobium symbiosis. New Phytol 83:745-754 0028-646X/79/ 060745

Gibson AH, Searle SD, Woods MJ, Brockwell J (1999) Variation in the effectivenss of symbiotic associations between native rhizobia and temperate Australian Acacia: within-species interactions. J Appl Ecol 36:398-408

Giller KE (2001) Nitrogen fixation in tropical cropping systems, 2nd edn. $\mathrm{CAB}$ Internaional, Wallingford

Giller KE, Franke AC, Abaidoo R et al (2013) N2Africa: putting nitrogen fixation to work for smallholder farmers in Africa. In: Vanlauwe B, van Asten PJA, Blomme G (eds) Agro-ecological intensification of agricultural systems in the African Highlands. Routledge, London, pp 156-174

Greenlon A, Chang PL, Damtew ZM, Muleta A, Carrasquilla-Garcia N, Kim D, Nguyen HP, Suryawanshi V, Krieg CP, Yadav SK, Patel JS,
Mukherjee A, Udupa S, Benjelloun I, Thami-Alami I, Yasin M, Patil B, Singh S, Sarma BK, von Wettberg EJB, Kahraman A, Bukun B, Assefa F, Tesfaye K, Fikre A, Cook DR (2019) Global-level population genomics reveals differential effects of geography and phylogeny on horizontal gene transfer in soil bacteria. Proc Natl Acad Sci U S A 116:15200-15209. https://doi.org/10.1073/pnas. 1900056116

Gunnabo AH, Geurts R, Wolde-meskel E, Degefu T, Giller KE, van Heerwaarden J (2019) Genetic interaction studies reveal superior performance of rhizobium tropici CIAT899 on a range of diverse east African common bean ( Phaseolus vulgaris L.) genotypes. Appl Environ Microbiol 85:1-19. https://doi.org/10.1128/aem.01763-19

Heath KD, Tiffin P (2007) Context dependence in the coevolution of plant and rhizobial mutualists. Proc R Soc B 274:1905-1912. https://doi.org/10.1098/rspb.2007.0495

Heath KD, Burke PV, Stinchcombe JR (2012) Coevolutionary genetic variation in the legume-rhizobium transcriptome. Mol Ecol 21: 4735-4747. https://doi.org/10.1111/j.1365-294X.2012.05629.x

Howieson JG, Dilworth MJ (2016) Working with rhizobia. ACIAR Monogr No 173:314

Hugh G (2006) Statistical analysis of yield trials by AMMI and GGE. Crop Sci 46:1488-1500. https://doi.org/10.2135/cropsci2007.09. 0513

Hungria M, Neves MCPP (1987) Cultivar and rhizobium strain effect on nitrogen fixation and transport in Phaseolus vulgaris L. Plant Soil 103:111-121. https://doi.org/10.1007/BF02370675

Imran A, Mirza MS, Shah TM, Malik KA, Hafeez FY (2015) Differential response of kabuli and desi chickpea genotypes toward inoculation with PGPR in different soils. Front Microbiol 6:1-14. https://doi. org/10.3389/fmicb.2015.00859

Keneni G, Bekele E, Getu E, Imtiaz M (2011) Characterization of Ethiopian Chickpea (Cicer arietinum L.) germplasm accessions for response to infestation by adzuki bean beetle (Callosobruchus chinensis L.) II . Phenotypic diversity. Ethiop J Agric Sci 83:66-83

Keneni G, Bekele E, Assefa F et al (2012a) Phenotypic diversity for symbio-agronomic characters in Ethiopian chickpea (Cicer arietinum L.) germplasm accessions. Afr J Biotechnol 11:12634 12651. https://doi.org/10.5897/AJB12.428

Keneni G, Bekele E, Imtiaz M, Dagne K, Getu E, Assefa F (2012b) Genetic diversity and population structure of Ethiopian chickpea (Cicer arietinum L.) germplasm accessions from different geographical origins as revealed by microsatellite markers. Plant Mol Biol Report 30:654-665. https://doi.org/10.1007/s11105-011-0374-6

Kumar S, Stecher G, Tamura K (2016) MEGA7: molecular evolutionary genetics analysis version 7.0 for bigger datasets. Mol Biol Evol 33: 1870-1874. https://doi.org/10.1093/molbev/msw054

Kumar S, Stecher G, Li M, Knyaz C, Tamura K (2018) MEGA X: molecular evolutionary genetics analysis across computing platforms. Mol Biol Evol 35:1547-1549. https://doi.org/10.1093/ molbev/msy096

Laguerre G, Depret G, Bourion V, Duc G (2007) Rhizobium leguminosarum bv. viciae genotypes interact with pea plants in developmental responses of nodules, roots and shoots. New Phytol 176:680-690

Laranjo M, MacHado J, Young JPW, Oliveira S (2004) High diversity of chickpea Mesorhizobium species isolated in a Portuguese agricultural region. FEMS Microbiol Ecol 48:101-107. https://doi.org/10. 1016/j.femsec.2003.12.015

Laranjo M, Alexandre A, Rivas R, VelÃ $i z q u e z$ E, Young JPW, Oliveira S (2008) Chickpea rhizobia symbiosis genes are highly conserved across multiple Mesorhizobium species. FEMS Microbiol Ecol 66: 391-400. https://doi.org/10.1111/j.1574-6941.2008.00584.x

Laranjo M, Young JPW, Oliveira S (2012) Multilocus sequence analysis reveals multiple symbiovars within Mesorhizobium species. Syst Appl Microbiol 35:359-367. https://doi.org/10.1016/j.syapm.2012. 06.002 
Laranjo M, Alexandre A, Oliveira S (2014) Legume growth-promoting rhizobia: an overview on the Mesorhizobium genus. Microbiol Res 169:2-17. https://doi.org/10.1016/j.micres.2013.09.012

Lindström K, Aserse AA, Mousavi SA (2015) Evolution and taxonomy of nitrogen-fixing organisms with emphasis on rhizobia. In: de Bruijn FJ (ed) Biological nitrogen fixation, 1st edn. John Wiley \& Sons Inc, pp 21-38

Maâtallah J, Berraho EB, Muñoz S et al (2002) Phenotypic and molecular characterization of chickpea rhizobia isolated from different areas of Morocco. J Appl Microbiol 93:531-540. https://doi.org/10.1046/j. 1365-2672.2002.01718.x

Montealegre C, Kipe-Nolt J (1994) Ability of selected accessions of Phaseolus vulgaris L. to restrict nodulation by particular rhizobia. Arch Microbiol 162:352-356. https://doi.org/10.1007/BF00263783

Mousavi SA, Li L, Wei G, Räsänen L, Lindström K (2016) Evolution and taxonomy of native mesorhizobia nodulating medicinal Glycyrrhiza species in China. Syst Appl Microbiol 39:260-265. https://doi.org/ 10.1016/j.syapm.2016.03.009

Mytton LR (1975) Plant genotype $\times$ rhizobium strain interactions in white clover. Ann Appl Biol 80:103-107 . https://doi.org/10.1111/j.17447348.1975.tb01604.x

Nandasena KG, O'Hara GW, Tiwari RP et al (2007) Mesorhizobium ciceri biovar biserrulae, a novel biovar nodulating the pasture legume Biserrula pelecinus L. Int J Syst Evol Microbiol 57:10411045. https://doi.org/10.1099/ijs.0.64891-0

Nandasena KG, O'Hara GW, Tiwari RP et al (2009) Mesorhizobium australicum sp. nov. and mesorhizobium opportunistum sp. nov., isolated from Biserrula pelecinus L. in Australia. Int J Syst Evol Microbiol 59:2140-2147. https://doi.org/10.1099/ijs.0.005728-0

Nour SM, Cleyet-Marel JC, Normand P, Fernandez MP (1995) Genomic heterogeneity of strains nodulating chickpeas (Cicer arietinum L.) and description of rhizobium mediterraneum sp. nov. Int J Syst Bacteriol 45(4):640-648. https://doi.org/10.1099/00207713-45-4640

Plekhanova E, Vishnyakova MA, Bulyntsev S, Chang PL, CarrasquillaGarcia N, Negash K, Wettberg E, Noujdina N, Cook DR, Samsonova MG, Nuzhdin SV (2017) Genomic and phenotypic analysis of Vavilov's historic landraces reveals the impact of environment and genomic islands of agronomic traits. Sci Rep 7:1-12. https://doi.org/10.1038/s41598-017-05087-5

Rai R, Singh SJ, Prasad V (1985) Interactions between rhizobium strains and lentil (Lens culinaris Linn.) genotypes under salt stress. J Agric Sci 104:199-205. https://doi.org/10.1017/S0021859600043124

Regus JU, Gano KA, Hollowell AC, Sofish V, Sachs JL (2015) Lotus hosts delimit the mutualism-parasitism continuum of Bradyrhizobium. J Evol Biol 28:447-456. https://doi.org/10.1111/ jeb. 12579

Rivas R, Velázquez E, Willems A et al (2002) A new species of Devosia that forms a unique nitrogen-fixing root-nodule symbiosis with the aquatic legume Neptunia natans (L.f.) Druce. Appl Environ Microbiol 68:5217-5222. https://doi.org/10.1128/AEM.68.11. 5217-5222.2002

Rivas R, Laranjo M, Mateos PF, Oliveira S, Martínez-Molina E, Velázquez E (2007) Strains of Mesorhizobium amorphae and Mesorhizobium tianshanense, carrying symbiotic genes of common chickpea endosymbiotic species, constitute a novel biovar (ciceri) capable of nodulating Cicer arietinum. Lett Appl Microbiol 44:412 418. https://doi.org/10.1111/j.1472-765X.2006.02086.x

Rodríguez-Navarro DN, Santamaría C, Temprano F, Leidi EO (1999) Interaction effects between rhizobium strain and bean cultivar on nodulation, plant growth, biomass partitioning and xylem sap composition. Eur J Agron 11:131-143. https://doi.org/10.1016/S11610301(99)00025-8

Shiferaw B, Asfaw S, Abate B et al (2009) Current situation and future outlooks of the chickpea sub-sector in Ethiopia. ICRISAT and EIAR, Nairobi
Somasegaran P, Hoben H (1994) Handbook for rhizobia: methods in legume-rhizobium technology. Springer-Verlag, New York

Somasegaran P, Abaidoo RC, Kumaga F (1990) Host-Bradyrhizobium relationships and nitrogen-fixation in the Bambarra groundnut [ Voandzeia subterranea (L.). Trop Agric (Trinidad) 67:137-142

Tamura K (1992) Estimation of the number of nucleotide substitutions when there are strong transition-transversion and $\mathrm{G}+\mathrm{C}$-content biases. Mol Biol Evol 4:678-687. https://doi.org/10.1093/ oxfordjournals.molbev.a040752

Tena W, Endalkachew W-M, Fran W (2016a) Response of chickpea (Cicer arietinum L.) to inoculation with native and exotic Mesorhizobium strains in southern Ethiopia. Afr J Biotechnol 15: 1920-1929. https://doi.org/10.5897/AJB2015.15060

Tena W, Wolde-Meskel E, Walley F (2016b) Symbiotic efficiency of native and exotic rhizobium strains nodulating lentil (Lens culinaris Medik.) in soils of southern Ethiopia. Agronomy 6:11. https://doi. org/10.3390/agronomy6010011

Tena W, Wolde-Meskel E, Degefu T, Walley F (2017) Genetic and phenotypic diversity of rhizobia nodulating chickpea (Cicer arietinum L.) in soils from southern and Central Ethiopia. Can J Microbiol 63: 690-707. https://doi.org/10.1139/cjm-2016-0776

Unkovich M, Herridge D, Peoples M et al (2008) Measuring plantassociated nitrogen fixation in agricultural systems. ACIAR, Canberra

van Heerwaarden J, Doebley J, Briggs WH, Glaubitz JC, Goodman MM, de Jesus Sanchez Gonzalez J, Ross-Ibarra J (2011) Genetic signals of origin, spread, and introgression in a large sample of maize land races. PNAS 108:1088-1092. https://doi.org/10.1073/pnas. 1013011108

Vishnyakova MA, Burlyaeva MO, Bulyntsev SV, Seferova IV, Plekhanova ES, Nuzhdin SV (2017) Phenotypic diversity of chickpea (Cicer arietinum L.) landraces accumulated in the Vavilov collection from the centers of the crop's origin. Russ J Genet Appl Res 7:763-772. https://doi.org/10.1134/S2079059717070097

Walley FL, Kyei-Boahen S, Hnatowich G, Stevenson C (2005) Nitrogen and phosphorus fertility management for desi and kabuli chickpea. Can J Plant Sci 85:73-79. https://doi.org/10.4141/P04-039

Wang ET, van Berkum P, Sui XH, Beyene D, Chen WX, MartínezRomero E (1999) Diversity of rhizobia associated with Amorpha fruticosa isolated from Chinese soils and description of Mesorhizobium amorphae sp. nov. Int J Syst Bacteriol 49:51-65. https://doi.org/10.1099/00207713-49-1-51

Weir BS, Cockerham CC (1984) Estimating F-statistics for the analysis of population structure. Evolution (N Y) 38:1358-1370 128.103.149.52

Wolde-meskel E, van Heerwaarden J, Abdulkadir B, Kassa S, Aliyi I, Degefu T, Wakweya K, Kanampiu F, Giller KE (2018) Additive yield response of chickpea (Cicer arietinum L.) to rhizobium inoculation and phosphorus fertilizer across smallholder farms in Ethiopia. Agric Ecosyst Environ 261:144-152. https://doi.org/10. 1016/j.agee.2018.01.035

Wynne JC, Elkan GH, Isleib TG, Schneeweis TJ (1983) Effect of host plant, rhizobium strain and host $\mathrm{x}$ strain interaction on symbiotic variability in peanut. Peanut Sci 10:110-114

Yan W, Hunt LA, Sheng Q, Szlavnics Z (2000) Cultivar evaluation and mega-environment investigation based on the GGE Biplot. Publ Crop Sci 40597-605(40):597-605

Zhang JJ, Liu TY, Chen WF, Wang ET, Sui XH, Zhang XX, Li Y, Li Y, Chen WX (2012a) Mesorhizobium muleiense sp. nov., nodulating with Cicer arietinum L. Int J Syst Evol Microbiol 62:2737-2742. https://doi.org/10.1099/ijs.0.038265-0

Zhang JJ, Lou K, Jin X, Mao PH, Wang ET, Tian CF, Sui XH, Chen WF, Chen WX (2012b) Distinctive Mesorhizobium populations associated with Cicer arietinum L. in alkaline soils of Xinjiang, China. Plant Soil 353:123-134. https://doi.org/10.1007/s11104-011-10145 
Zhang JJ, Yu T, Lou K, Mao PH, Wang ET, Chen WF, Chen WX (2014) Genotypic alteration and competitive nodulation of Mesorhizobium muleiense against exotic chickpea rhizobia in alkaline soils. Syst Appl Microbiol 37:520-524. https://doi.org/10.1016/j.syapm.2014. 07.004

Zhang J, Guo C, Chen W, de Lajudie P, Zhang Z, Shang Y, Wang ET (2018) Mesorhizobium wenxiniae sp. Nov., isolated from chickpea (cicer arietinum L.) in China. Int J Syst Evol Microbiol 68:19301936. https://doi.org/10.1099/ijsem.0.002770

Zhang J, Peng S, Shang Y, Brunel B, Li S, Zhao Y, Liu Y, Chen W, Wang E, Singh RP, James EK (2020) Genomic diversity of chickpea-nodulating rhizobia in Ningxia (north Central China) and gene flow within symbiotic Mesorhizobium muleiense populations. Syst Appl Microbiol 43:126089. https://doi.org/10.1016/j.syapm. 2020.126089
Zhao CT, Wang ET, Zhang YM, Chen WF, Sui XH, Chen WX, Liu HC, Zhang XX (2012) Mesorhizobium silamurunense sp. nov., isolated from root nodules of astragalus species. Int J Syst Evol Microbiol 62:2180-2186. https://doi.org/10.1099/ijs.0.031229-0

Zobel RW, Wright MJ, Gauch HG (1988) Statistical analysis of a yield trial. Agron J 80:388-393. https://doi.org/10.2134/agronj1988. $00021962008000030002 x$

Zohary D, Hopf M (1973) Domestication of pulses in the Old World. Sci New Ser 182:887-894

Publisher's note Springer Nature remains neutral with regard to jurisdictional claims in published maps and institutional affiliations. 